\title{
最先端の欠陷検査システムとワインダー支援システムの活用例
}

\section{Enhanced Use of Advanced Web Inspection System and Winder Advisor System}

Atsushi Kurosaki

Surface Inspection Systems Division, COGNEX K.K.

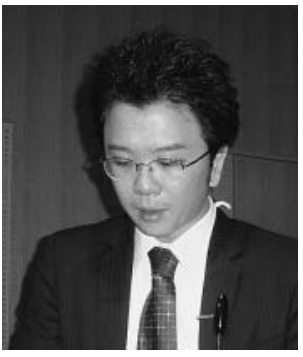

Cognex developed “SmartLearn ${ }^{\circledR}$, a useful 1 classification tool. It was designed such that the latest learning classification technology can be combined with expert knowledge of each application. SmartLearn dramatically improves defect classification accuracy.

The usage of “AWA (Advanced Winder Advisor)” further streamlines the re-reeling process. Automatic and accurate stopping at desired defect positions improves winder operation not seen before.

分類 $: \mathrm{V}_{2}$ 紙パルプ工程制御システム, $\mathrm{V}_{3}$ 紙パルプ工程計器およびセンサ

\section{1. はじめに}

コグネックス社は欠陥検査システム「SmartView ${ }^{\circledR}$ (ス マート・ビュー)」を 2000 年にリリースして以来, 紙パ業 界向けに常に新しい検査技術を紹介し，抄紙・塗工から仕 上工程まで幅広く活用されてきた。コグネックスがこれま で提案してきた「久陥を画像判定で分類する機能」も，紙 パの検査において必要不可欠な機能となりつつある。さら に，コグネックスが新たに開発した「SmartLearn ${ }^{\circledR}$ (スマ ート・ラーン)」は, 検査を重ねてサンプル数を増やすこ とで，欠陥の分類精度を向上させることができる“学習型 の欠陷分類支援ツール”である。これにより，ユーザーは 簡単な設定で正確な欠陥判定を行うことができる。

一方， 欠陥情報の有効活用の面においては，リリーラー やワインダーを欠陥位置で正確に停止させる「AWA（ア ドバンスト・ワインダー・アドバイザー)」システムが, 欠陷処置の効率化に大きく貢献している。

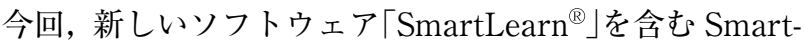
View 欠陥検査システムの最新の技術動向を解説するとと もに，仕上げ工程における AWA の活用例を紹介する。

\section{2. 最新の欠陥検査技術}

2.1 SmartView 検査システムのコンセプト まず最初に, SmartView 欠陷検査システムのコンセプ
トを確認しておく。本システムは, CCD ラインカメラよ りデジタル信号を受信し，デジタル信号補正を行い，補正 された信号にしきい值処理をする。しきい值にかかったも のは欠陷の候補となり，フィル夕/連結処理により，ノイ ズを消去したり，欠陥を連結したりする。そして，欠陷画 像の特徵量を抽出し，你分類テーブルに設定された特徴 量のパラメータに基づいて, 分類（画像判定）される（図 1)。

今回，新たに開発された学習型の分類ソフトウェア 「SmartLearn（スマート・ラーン）」は，この「分類（画 像判定)」の機能を強化したものである。

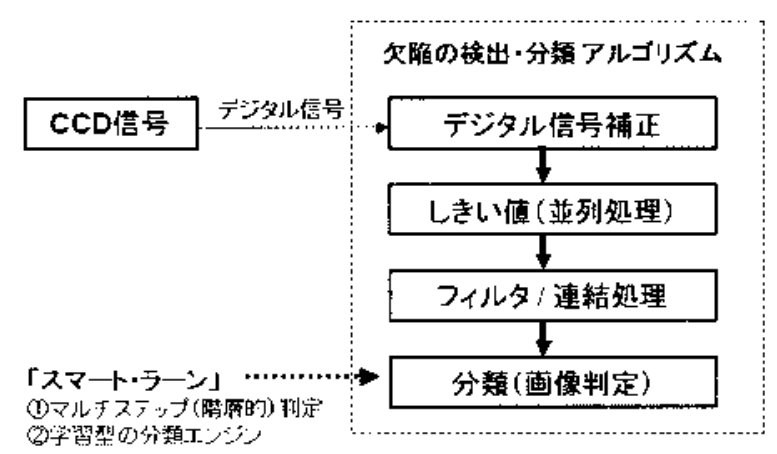

図 1 検査システムのアルゴリズム 


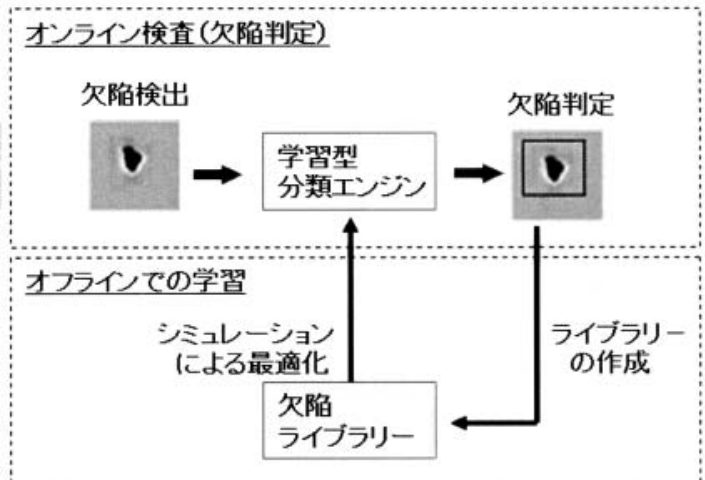

図 2 分類エンジンの学習サイクル（フィードバック）

\subsection{SmartLearn $^{\circledR}$ (スマート・ラーン)}

「スマート・ラーン」の大きな特長は学習型の分類エン ジンを持ち，パラメータを意識することなく簡単に，かつ 正確に欠陥を判定（分類）することができる点にある。判 定したい欠陥，例えば「油」などを欠陥ライブラリー（過 去に検出した欠陥種別ごとデータ）に登録しておけば，シ ミュレーションによって「油」を最適に分類するパラメー 夕を導き出すことができる。

ここでいう「学習型」とは，検出した欠陥を登録し欠陥 データを蓄積していくことで，判定の精度が上がっていく ことを意味している。図 2 に分類エンジンの学習サイクル (フィードバック）を示す。

\section{AWA(アドバンスト・ワインダー・アドバイザー) の活用例}

3.1 AWA のコンセプト

「AWA（アドバンスト・ワインダー・アドバイザー）」 は，上流側で SmartView（スマート・ビュー）欠陥検査 システムが精度の高い検査を行った結果に対して，リーラ 一およびワインダーを欠陥位置で正確に停止させ，ワイン ダーでの作業効率を飛躍的に向上させるシステムである。 AWAの概念図は，以下のようになる（図 3）。

1）上流側（抄紙機またはコーター）

SmartView（スマート・ビュー）你検査システムが 欠陥を検出・分類し，ロール毎に検査ファイルを生成する。 検査ファイルは LAN を通じて外部 PCおよび AWA サバから，欠陥マップ画面や欠陷画像などを見ることもでき る。マーカーは，検査システムの指令により，定期的に流 れ方向の絶対位置をコーディングする。

2）下流側（リリーラー，ワインダー）

上流側で検査した結果（検査ファイル）から処置すべき 欠陷を選択し，ワインダーを運転する。コード・リーダー はコードを読み取り，その情報をもとにシステムは選択さ れた欠陥位置で正確にワインダーが自動停止するように指 令を出す。

AWA は，上流側（抄紙機，コーター）に常に距離をコ ーディングする特殊なマーカーを採用している。マーカー は，検査システムの指令によって，10 m または $20 \mathrm{~m}$ おき にコードをマーキングしていく（図 4)。下流側（ワイン ダー）にこのマークを検出するカメラを設置しコードを解

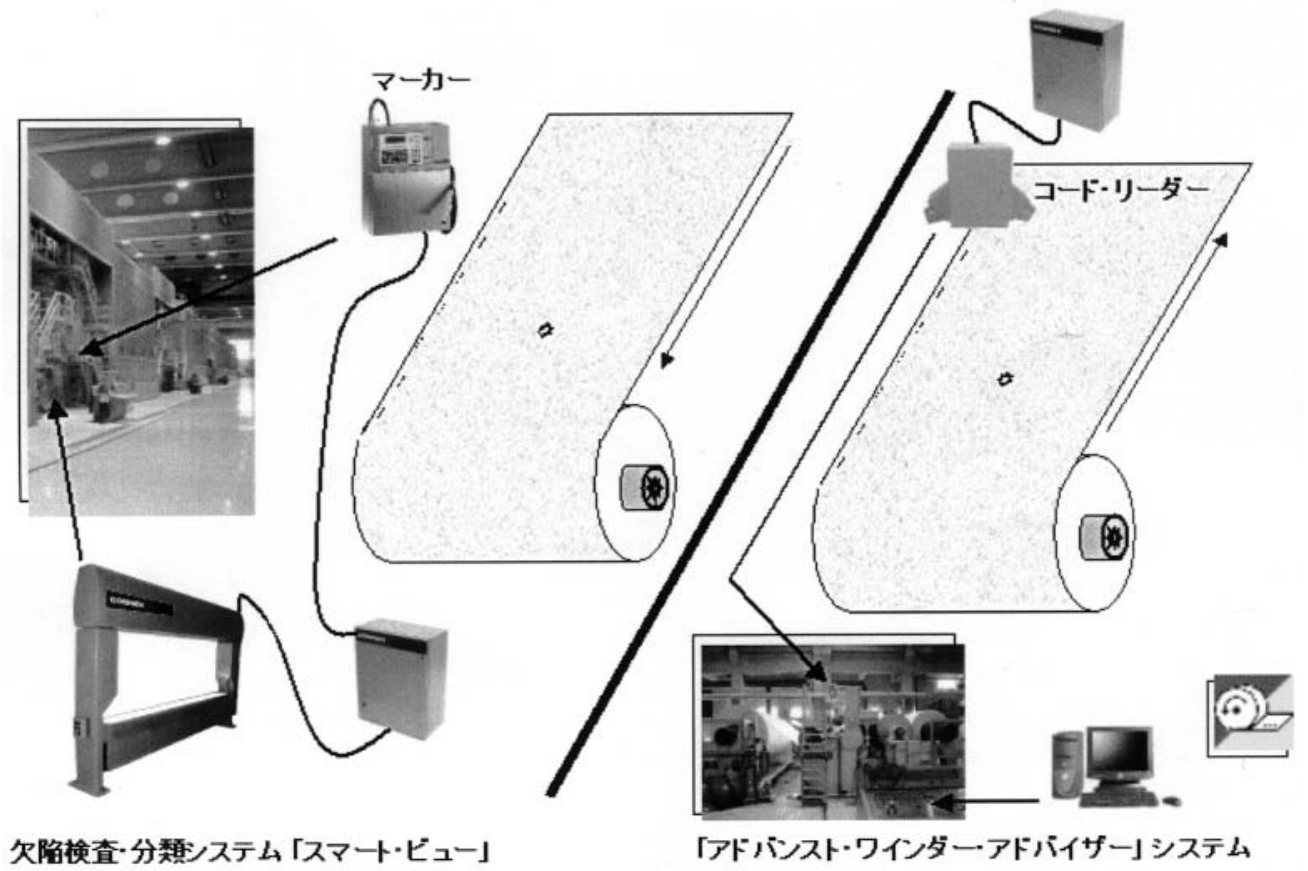

図３ワインダー・コントロールのシステム概念図 


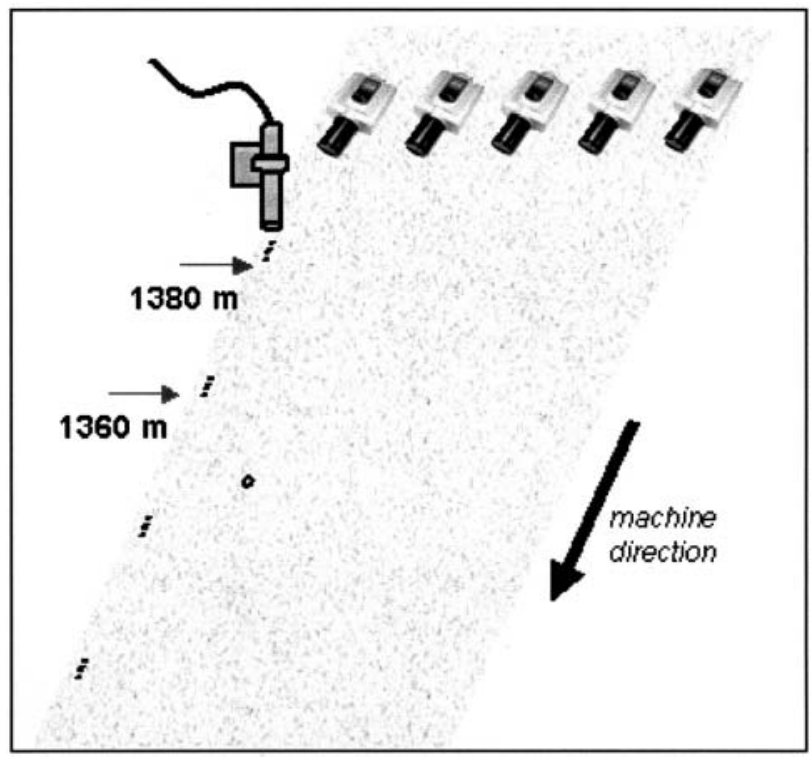

図 4 上流側でのマーキング方法

読すれば，検査システムの結果（距離情報）とシンクロし， 正確な位置でワインダーを停止することができる。この方 法で，停止精度を $\pm 10 \mathrm{~cm}$ に抑えることができる。

\subsection{AWA の運転}

AWA を導入したワインダーの運転は次のように行われ る。

一「停止リスト」の作成・運転開始一

(1) オペレータはワインダーにかかるリールの枠番号を 確認し，上流の欠陥検査システムょり，同じ枠番号の 検査ファイルを取得する。

(2) 画面上に「停止リスト」（分類された欠陥クラスの 中から処置すべきと思われる重欠陥がリストアップさ

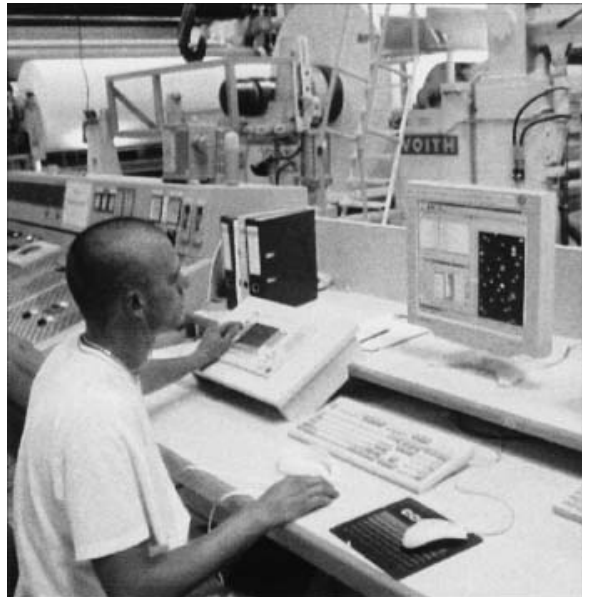

写真 1 ワインダーで停止リストを作成するオペレータ

れている）が表示されているので，欠陷画像を確認し ながら停止（または徐動）すべきところにチェックを 入れていく。

(3) 任意に停止したい箇所があればその位置を入力し, ワインダーをスタートする。

写真 1 にワインダー停止リストを作成するオペレータを 示す。

一運 転 開 始一

(4) 画面には次に停止する欠陥の画像が表示される。

(5) システムは「低速」「徐動」「停止」の 3 種類の信号 を出力し， 欠陥の位置で正確にワインダーを自動停止 させる。

図 5 にワインダー運転中の画面を示す。

一オペレータの処置一

(6) オペレータは，欠陷を取り除きパッチをあてる，な

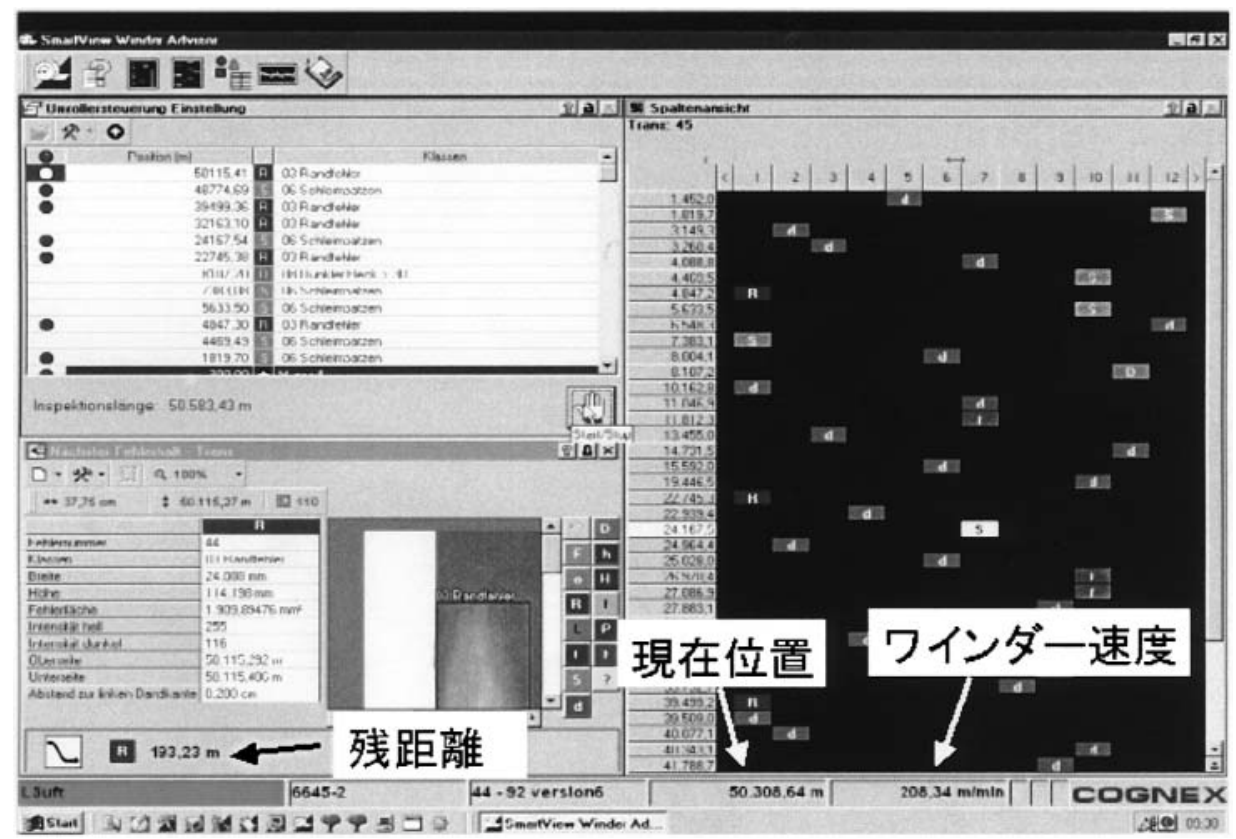

図 5 ワインダー運転中の画面 


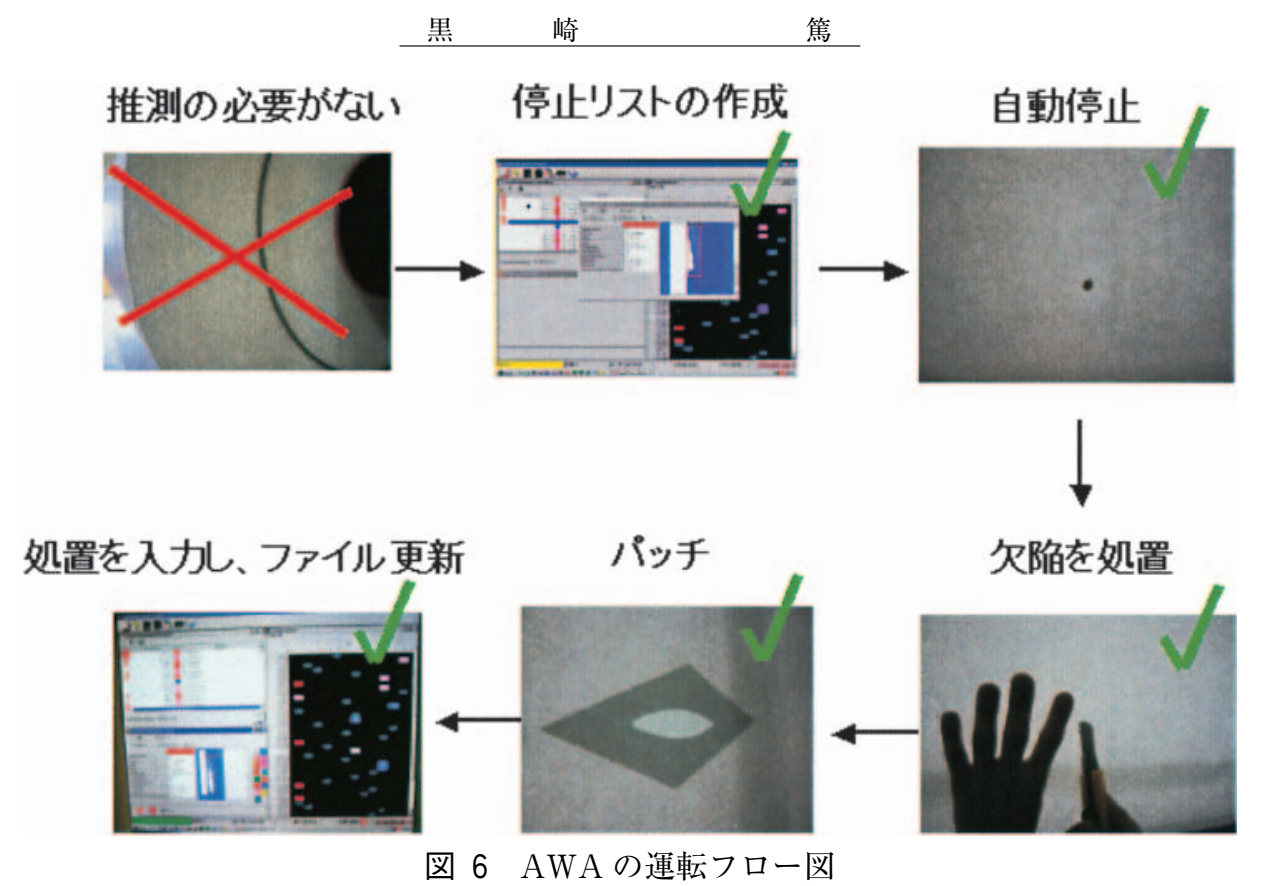

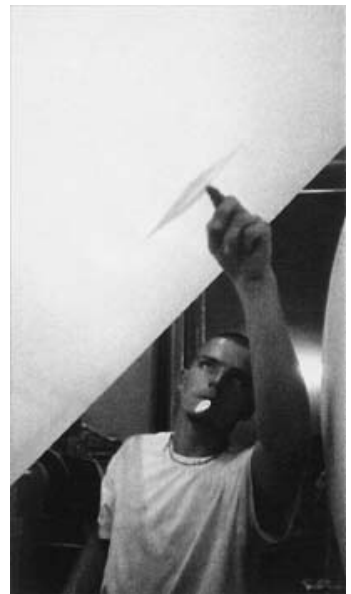

写真 2 正確な位置で自動停止した欠陥にパッチをあてる

ど処置を行う。

(7) 処置した欠陥について，検査ファイル上の欠陥クラ ス名を書き直す。例えば，「穴」という欠陥クラスか ら「パッチ」というクラスに変更（再分類）する。

(8) ワインダーを再スタートさせ，次の欠陥のところで， 自動停止させる。

写真 2 に正確な位置で自動停止した欠陥にパッチをあて るを，図6にAWAの運転フロー図を示す。

\subsection{AWA の活用例}

SmartView 欠陷検査システムと AWA（アドバンスト ・ワインダー・アドバイザー）の連携により，次のような 効果を上げている。

・リリーラー/ワインダーでの作業効率アップ

・ワインダーでの作業速度のアップ。

・オペレータがワインダーを離れて仕事ができる。

・処置すべき欠陥を $100 \%$ 対処することが可能となった。

・不必要なワインダー停止作業（無䭾な欠陥の確認）の 削減。

\section{4.おわりに}

コグネックス社の提唱してきた画像による「久陷の分類 (判定)」については，紙パ業界の中でも支持され，最近の 検査システムの開発の流れをつくったように感じる。画像 処理の分野はコグネックスの得意とするところであり，今 後も新機能の開発に力を注ぎたい。一方，情報システムの 開発も強化しており，「AWA（アドバンスト・ワインダ 一・アドバイザー)」はその一環ある。欠陷検査システム の情報・能力をワインダーにて最大限利用できるシステム である。今後も, 現場のニーズに捉えながら一層の製品開 発を行い, 市場へ新しい製品を投入していきたいと考えて いる。 